\title{
Design, Synthesis and Optimization of 7-substituted- pyrazolo[4,3- b]pyridine ALK5 (activin receptor-like kinase 5) inhibitors
}

\author{
Mark Sabat*, Haixia Wang, Nick Scorah, J. David Lawson, Joy Atienza, Ruhi Kamran, Mark S. Hixon \\ Douglas R. Dougan
}

Takeda California; 10410 Science Center Drive, San Diego, CA, 92121

\begin{abstract}
A series of potent ALK5 inhibitors were designed using a SBDD approach and subsequently optimized to improve drug likeness. Starting with a 4-substituted quinoline screening hit SAR was conducted using a ALK5 binding model to understand the binding site and optimize activity. The resulting inhibitors displayed excellent potency but were limited by high in vitro clearance in rat and human microsomes. Using a scaffold morphing strategy, these analogs were transformed into a related pyrazolo[4,3-b]pyridine series with improved ADME properties.
\end{abstract}

\begin{abstract}
ALK5 (activin-like kinase 5, also known as TGF- $\beta$ RI / transforming growth factor $\beta$ receptor I) is a receptor serine-threonine kinase that has a role in the regulation of a variety of physiological processes. ${ }^{1 a}$ TGF- $\beta$ ligands initially bind TGF- $\beta$ RII which recruits and phosphorlyates ALK5 (TGF- $\beta$ RI). The activated ALK5 then phosphorylates SMAD2/SMAD3 proteins which dissociate from the receptor and form a heteromeric complex with SMAD4. This complex eventually translocates to the nucleus and interacts with DNA cofactors to regulate gene expression controlling cell growth, differentiation and development. Thus, modulation of TGF- $\beta$ signaling via small-molecule ALK5 inhibitors has been considered a potential treatment of fibrotic disease $\mathrm{e}^{\mathrm{lj}, \mathrm{k}}$ and cancer. The role of TGF- $\beta$ in cancer biology is complex with both promoter and suppressor functions depending on cancer stage. During late stages of carcinogenesis tumor cells utilize the TG signaling system to promote metastatic spread and overcome immune surveillance. ${ }^{1 \mathrm{~b}, \mathrm{c}}$ This later role of TGF- $\beta$ makes it a particularly attractive target to combat the most invasive and metastatic cancers particularly in brain and pancreas.
\end{abstract}

Modulating ALK5 with small molecule inhibitors has received pharmaceutical industry attention, however to date only two small molecules LY2157299 and EW-7197 have entered clinical trials. ${ }^{1 b, d, 2}$ In this paper, we describe our efforts to identify potent and selective small molecule inhibitors of ALK5 and their subsequent optimization to yield an orally bio-available candidate which advanced into toxicological testing.
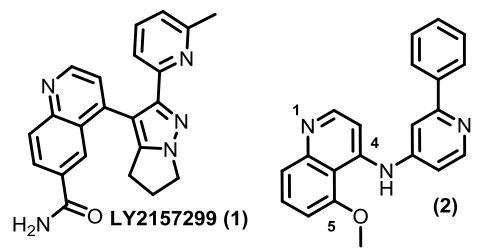

Figure1. Structures of ALK5 inhibitor LY2157299 (1) and screening hit based lead (2)

Screening of our internal compound collection followed by deconstruction afforded the early lead molecule 2 which displayed reasonable potency in the ALK5 enzymatic assay (ALK5 $\left.\mathrm{pIC}_{50}=6.2\right)^{3}$. Compound 2 was docked into the ATP binding site of the ALK5 protein using coordinates disclosed in the literature ${ }^{4}$ (see Fig 2). Compound 2 was predicted to adopt a binding pose that positions the quinoline ring nitrogen to make an H-bond with the backbone $\mathrm{NH}$ of $\mathrm{His}_{283}$ at the kinase's hinge region. In this pose, a potential pseudo hydrogen bond is also formed between the $\mathrm{C}-\mathrm{H}$ at position $\mathrm{C} 2$ of the quinoline ring and the carbonyl oxygen of $\mathrm{Asp}_{281}$. The pyridyl ring of compound $\mathbf{2}$ is positioned to hydrogen bond with the side chain amino group of Lys $_{232}$ as well as with a conserved water molecule that is coordinated by $\mathrm{Asp}_{351}, \mathrm{Glu}_{245}$ and $\mathrm{Tyr}_{249}$. Finally, the phenyl ring (which is attached at the $\mathrm{C} 2$ ' position of pyridine ring) is oriented towards the back hydrophobic pocket.

Figure 2. Molecular model of early quinoline screening lead (2) docked into the ALK5 nucleotide binding site.

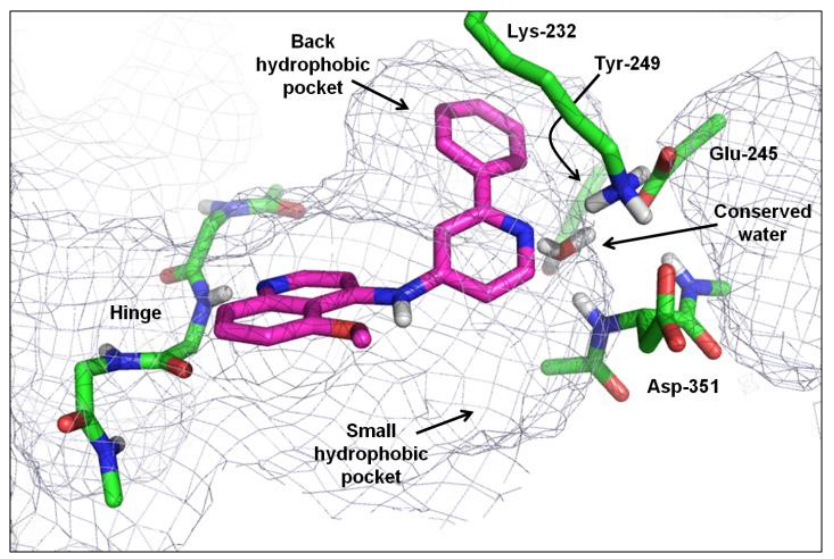

Using the hypothesized binding insights, initial optimization efforts on this series were targeted at improving enzymatic potency and obtaining a better understanding of the importance of the various hydrophobic pocket groups (described in the ALK5 literature ${ }^{5}$ ) (Table 1). Additionally we also attempted to optimally fill a small hydrophobic pocket (observed in the docked model of lead molecule 2 in ALK5) located directly below the $\mathrm{C} 5$ position of the pyridyl ring of compound $\mathbf{2}$ (see Fig 2).

Synthetic methodology used to access the elaborated quinolines (2-11) is described in Scheme $1 .^{6}$

Scheme 1 


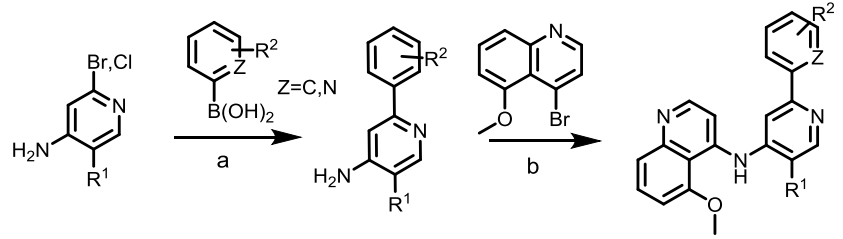

Scheme 1. Reagents and conditions: (a) $\mathrm{Pd}_{2}\left(\mathrm{PPh}_{3}\right)_{4}, \mathrm{~K}_{2} \mathrm{CO}_{3}$ aq, 1,4dioxane, $120^{\circ} \mathrm{C} 0.5 \mathrm{~h} \mathrm{MW}$; (b) $\mathrm{Pd}_{2}(\mathrm{dba})_{3}, \mathrm{NaOt} \mathrm{Bu}$, XANTPHOS, 1,4dioxane, $100{ }^{\circ} \mathrm{C} 1 \mathrm{~h} \mathrm{MW}$

Substitution at the meta position on the phenyl ring in $\mathbf{2}$ with a $\mathrm{Cl}$ atom gave a modest increase in potency (3). Installation of $\mathrm{a} \mathrm{CH}_{3}$ group at $\mathrm{R}^{1}$ further improved potency by filling a small lipophilic grove in the ALK5 model. Installation of a 5-chloro-2-fluorophenyl at $\mathrm{R}$ of the core further improved potency (compound 5). Modeling suggested the incorporation of a $\mathrm{F}$ atom (compound 5) helped to improve the orientation of the aromatic ring in the hydrophobic pocket. Next we looked at substituent size at position $\mathrm{R}^{1}$ (compounds 6-8) holding the ring at position $\mathrm{R}$ (5-chloro2 -fluorophenyl) constant. Unfortunately increased size at $\mathrm{R}^{1}$ resulted in decreased enzyme potency (compare 6 vs. $7 \& 8$ ) and thus a methyl group at $\mathrm{R}^{1}$ was judged optimal. Exchange of the 5-Cl for a methyl group in analogs $\mathbf{9}$ and $\mathbf{1 0}$ afforded similarly potent analogs (compare $\mathbf{1 0}$ vs. 6). Finally introduction of a 5-fluoro-2-methylpyridine group at position $\mathrm{R}$ afforded a potent analog with improved efficiency (compare 9 vs. 11; LLE $^{7 a} 3.6$ vs. 4.1).

Table 1. Selected data for 4-substituted quinoline analogues

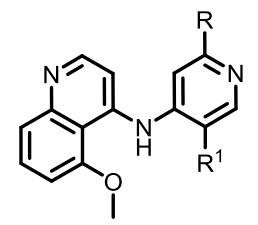

\begin{tabular}{|c|c|c|c|c|}
\hline Cmpd & $\mathbf{R}$ & $\mathbf{R}^{1}$ & LLE & $\mathrm{pIC}_{50}$ \\
\hline 2 & Phenyl & $\mathrm{H}$ & 2.6 & 6.2 \\
\hline 3 & 3-chlorophenyl & $\mathrm{H}$ & 2.4 & 6.5 \\
\hline 4 & 3-chlorophenyl & $\mathrm{CH}_{3}$ & 3.2 & 7.5 \\
\hline 5 & $\begin{array}{l}5 \text {-chloro-2- } \\
\text { fluorophenyl }\end{array}$ & $\mathrm{H}$ & 3.6 & 7.7 \\
\hline 6 & $\begin{array}{l}5 \text {-chloro-2- } \\
\text { fluorophenyl }\end{array}$ & $\mathrm{CH}_{3}$ & 3.5 & 7.9 \\
\hline 7 & $\begin{array}{l}\text { 5-chloro-2- } \\
\text { fluorophenyl }\end{array}$ & $\mathrm{CH}_{3} \mathrm{CH}_{2}$ & & 7.6 \\
\hline 8 & $\begin{array}{l}5 \text {-chloro-2- } \\
\text { fluorophenyl }\end{array}$ & $\xi$ & 2.6 & 7.3 \\
\hline 9 & $\begin{array}{l}5 \text {-methyl-2- } \\
\text { fluorophenyl }\end{array}$ & $\mathrm{H}$ & 3.6 & 7.6 \\
\hline 10 & $\begin{array}{l}\text { 5-methyl-2- } \\
\text { fluorophenyl }\end{array}$ & $\mathrm{CH}_{3}$ & 3.7 & 7.9 \\
\hline 11 & $\begin{array}{c}\text { 3-fluoro-6- } \\
\text { methylpyridin-2-yl }\end{array}$ & $\mathrm{H}$ & 4.1 & 7.4 \\
\hline
\end{tabular}

$L L E=p(I C 50)-\log D$ see ref. 7a

Although the quinoline series of compounds showed good ALK5 enzyme and cellular potency (data not shown) most examples displayed high in vitro clearance in rat and human microsomes and substantial
$\mathrm{hERG}^{14 \mathrm{~b}}$ inhibition. As an example analog 6 displayed an in vitro clearance of $302(\mathrm{R})$ and $86(\mathrm{H}) \mathrm{mL} / \mathrm{min} / \mathrm{kg}$. Additionally the series suffered elevated hERG inhibition with compound 6 showing $94 \%$ inhibition at $10 \mathrm{uM}$. Both liabilities were partially attributed to the high lipophilicity of the series (compound $6 \mathrm{cLogD}=4.4$ ).

Using a scaffold morphing strategy, the quinoline series was transformed into the related 7-substituted-pyrazolo[4,3-b]pyridine series. The replacement of a phenyl ring with a pyrazole resulted in a reduction of lipophilicity (contrast LLE values between Tables $1 \& 2$ )

The chemistry methodology used to access the appropriate 7-substitutedpyrazolo[4,3-b]pyridines (12-18) is described in Scheme $2^{8}$, and their biological properties are disclosed in Table 2 .

\section{Scheme 2}

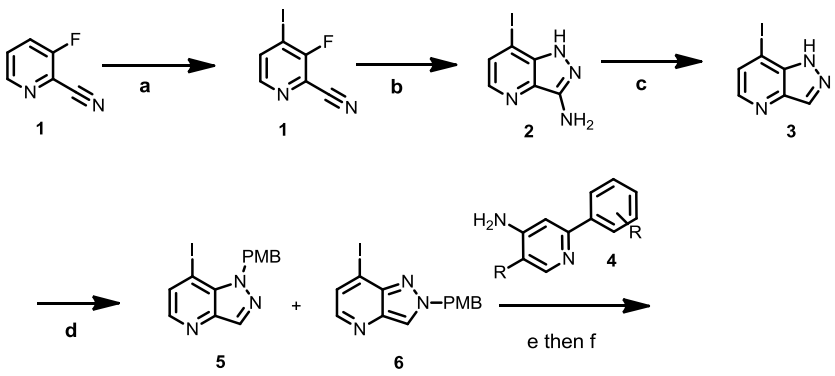

Scheme 2. Reagents and conditions: (a) Lithium diisopropylamide, $\mathrm{I}_{2}$, THF, -78 to $0^{\circ} \mathrm{C}$; (b) $\mathrm{NH}_{2} \mathrm{NH}_{2}, \mathrm{n}-\mathrm{BuOH}, 105^{\circ} \mathrm{C}$; (c) $\mathrm{NaNO}_{2}, \mathrm{HI}, \mathrm{AcOH}$, DME, 0 to $80^{\circ} \mathrm{C}$; (d) $\mathrm{NaH}, 1$-(chloromethyl)-4-methoxybenzene, DMF;(e) NaOtBu, BINAP, Pd(OAc) $)_{2}$; (f) TFA, DCM

Table 2. Selected data for 7-substituted-pyrazolobpyridine

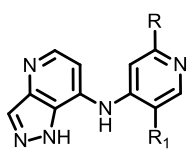

\begin{tabular}{|c|c|c|c|c|c|c|}
\hline Cmpd & $\mathbf{R}$ & R1 & LLE & pIC50 & pEC50* & pEC50 $\dagger$ \\
\hline 12 & 5-chloro-2-fluorophenyl & $\mathrm{H}$ & 5.3 & 8.2 & 7.3 & - \\
\hline 13 & 5-methyl-2-fluorophenyl & $\mathrm{H}$ & 5.1 & 7.8 & - & - \\
\hline 14 & 2,5-difluorophenyl & $\mathrm{H}$ & 5.8 & 8.1 & 7.4 & 6.7 \\
\hline 15 & 5-chloro-2-fluorophenyl & $\mathrm{CH}_{3}$ & 4.7 & 7.8 & 7.5 & - \\
\hline 16 & 2,5-difluorophenyl & $\mathrm{CH}_{3}$ & 6.5 & 9.0 & 8.1 & 7.5 \\
\hline 17 & 6-methylpyridin-2-yl & $\mathrm{CH}_{3}$ & 6.5 & 8.3 & 7.5 & 6.7 \\
\hline 18 & $\begin{array}{l}\text { 3-fluoro-6- } \\
\text { methylpyridin-2-yl }\end{array}$ & $\mathrm{CH}_{3}$ & 6.5 & 8.6 & - & 7.5 \\
\hline
\end{tabular}

The utilization of a pyrazolo[4,3-b]pyridine hinge binding element in place of the quinoline afforded more efficient inhibitors of ALK5 as evidenced by liphophilic ligand efficiencies values (compare analog LLEs for 2-11 vs. 12-18) as well as improved enzyme and cell potencies.

Installation of either a 5-chloro-2-fluorophenyl or 5-methyl-2fluorophenyl group (analogs $12 \& 13$ ) at position $R$ of the pyrazolo[4,3b]pyridine core afforded improved potency with lower lipophilicity and a marked improvement in LLE (compare 12 vs. 5 and 13 vs. 9). Addi- 
tionally, exchange of a $\mathrm{F}$ atom for $\mathrm{Cl}$ or $\mathrm{CH}_{3}$ (analogs 13 \& 14) resulted in comparable potency with a decrease in lipophilicity. Installation of a $\mathrm{CH}_{3}$ group at $\mathrm{R}^{1}$ similar to analogs in the quinoline series at first did not offer an increase in potency (compare 15 vs 12); however in case of the $\mathrm{R}=2$,5-difluorophenyl analogs, a $8 \mathrm{x}$ increase in potency was observed (compare 16 vs. 14). Keeping $\mathrm{CH}_{3}$ at position $\mathrm{R}^{1}$ constant and installing 2-methylpyridine (analog 17) or 5-fluoro-2-methylpyridine at position $\mathrm{R}$ afforded slightly less potent but equally efficient ALK5 inhibitors. Inhibitors 12-18 additionally showed cellular potency in both a functional assay (Reporter Inh Cell Line 293T SBE-bla) and in a MOA (mechanism of action) cell assay (pSMAD). ${ }^{9}$

The most promising analogs from the 7-substituted- pyrazolo[4,3b]pyridine series (highest cellular potency) were further profiled to assess their in vitro ADME properties. Compounds 15-16 \& 18 displayed high metabolic clearance and in vitro extraction ratios. Additionally these analogs showed elevated Cyp profiles particularly isoforms $2 \mathrm{C} 8$ and 3A4 (Table 3) despite the reduction in lipophilicity.

Table 3. Selected In Vitro ADME data for Compounds 15-18

\begin{tabular}{cccc}
\hline Cmpd & cLogD & $\begin{array}{c}\text { Eh } \\
(\mathbf{H} / \mathbf{R}) \\
\mathbf{m L} / \mathbf{m i n} / \mathrm{kg}\end{array}$ & $\begin{array}{c}\text { CYP2C8/ } \\
\text { CYP3A4 }\end{array}$ \\
\hline $\mathbf{1 5}$ & 2.9 & $.57 / .75$ & $6.4 / 5.5$ \\
$\mathbf{1 6}$ & 2.5 & $.74 / .84$ & $6.5 / 5.8$ \\
18 & 2.2 & $.57 / .74$ & $5.6 / 5.2$
\end{tabular}

$\mathrm{E}_{\mathrm{h}}=\mathrm{Cl}_{\mathrm{h}} / \mathrm{Q}_{\mathrm{h}}$ where $\mathrm{E}_{\mathrm{h}}=$ Hepatic extraction ratio; $\mathrm{Cl}_{\mathrm{h}}=$ Clearance hepatic $(\mathrm{mL} / \mathrm{min} / \mathrm{kg}) ; \mathrm{Q}_{\mathrm{h}}=$ Hepatic blood flow see ref. $7 \mathrm{~b}-\mathrm{c}$

Cytochromes P450 (CYPs) family (2C8 \& 3A4) pIC $_{50}$

To improve metabolic stability and reduce Cyp inhibition we decided to further reduce lipophilicity through the installation of polar substituent onto the lead examples (molecules 15-16 \& 18, Table 2). Based on the binding model developed for these compounds in ALK5 protein, both the quinoline ring nitrogen (required for good hinge binding) and the pyridine nitrogen (needed for interaction with the conserved water) did not allow for nearby substitutions. Only the N1 and N2 positions of the pyrazolo[4,3-b]pyridine in this series appeared to be open for modification. We were gratified that many analogs having substituents at these positions (Tables 4-7) showed enzyme and cell potency along with improved metabolic profiles. The chemistry to access the N1 and N2 substituent involved simple alkylation, separation and characterization and is described in our patent application. ${ }^{8}$

Table 4. Selected data for Compounds N1 substituted compounds<smiles>[X]c1ccc(F)c(-c2cc(Nc3ccnc4cnn([R])c34)c([R])cn2)c1</smiles>

\begin{tabular}{|c|c|c|c|c|c|c|c|}
\hline$\underset{\text { d }}{\text { Cmp }}$ & $\mathbf{X}$ & $\mathbf{R}^{1}$ & $\mathbf{R}^{2}$ & $\mathrm{pIC}_{50}$ & $\begin{array}{c}\text { pEC }_{50} \\
\text { SBE-bla }\end{array}$ & $\begin{array}{c}\mathrm{pEC}_{50} \\
\mathrm{pSM} \\
\mathrm{AD} 2 / \\
3 \\
\end{array}$ & $\operatorname{Eh}(\mathbf{H} / \mathbf{R})$ \\
\hline 19 & $\mathrm{~F}$ & & $\mathrm{H}$ & 7.3 & 6.7 & 5.9 & $.53 / .57$ \\
\hline 20 & $\mathrm{~F}$ & & $\mathrm{H}$ & 8.6 & 7.7 & 6.9 & $.55 / .27$ \\
\hline 21 & $\mathrm{~F}$ & & $\mathrm{H}$ & 8.3 & 7.5 & 6.8 & $.53 / .29$ \\
\hline
\end{tabular}

\begin{tabular}{|c|c|c|c|c|c|c|c|}
\hline 22 & $\mathrm{~F}$ & & $\mathrm{CH}_{3}$ & 9.0 & 7.6 & 7.7 & $<.23 / .2$ \\
\hline 23 & $\mathrm{~F}$ & & $\mathrm{CH}_{3}$ & 8.5 & 8.1 & 7.7 & $.64 / .54$ \\
\hline 24 & $\mathrm{Cl}$ & & $\mathrm{H}$ & 8.5 & 7.6 & 7.2 & $.57 / .31$ \\
\hline 25 & $\mathrm{Cl}$ & & $\mathrm{CH}_{3}$ & 7.8 & 7.5 & - & $.51 / .52$ \\
\hline 26 & $\mathrm{Cl}$ & & $\mathrm{CH}_{3}$ & 7.9 & 7.7 & 7.5 & $.54 / .44$ \\
\hline & $\mathrm{Cl}$ & & $\mathrm{H}$ & 5.6 & - & - & $.91 / .93$ \\
\hline
\end{tabular}

$\mathrm{E}_{\mathrm{h}}=\mathrm{Cl}_{\mathrm{h}} / \mathrm{Q}_{\mathrm{h}}$ where $\mathrm{E}_{\mathrm{h}}=$ Hepatic extraction ratio; $\mathrm{Cl}_{\mathrm{h}}=$ Clearance hepatic $(\mathrm{mL} / \mathrm{min} / \mathrm{kg}) ; \mathrm{Q}_{\mathrm{h}}=$ Hepatic blood flow see ref. $7 \mathrm{~b}-\mathrm{c}$

Substitution at $\mathrm{R}^{1}$ with acetamide (19), N-methylcarboxamide (20) and $\mathrm{N}$-ethylcarboxamide (21) to the N1 position of the difluorophenyl analogs indicated that N-methyl was optimal for enzyme potency. Incorporation of a $\mathrm{CH}_{3}$ group at $\mathrm{R}^{2}$ (compounds 22 and $\mathbf{2 3}$ ) further boosted potency and reduced in vitro clearance for compound 22 . A similar set of design changes for the 5-chloro-2-fluorophenyl analogs 24-26 did not have the same potency effect in regard to the $\mathrm{CH}_{3}$ group at $\mathrm{R}^{2}$ (data consistent with trend seen in Table 2 ex. 15)

A similar set of changes at position $\mathrm{R}^{2}$ of the pyridine ring (Table 5) was also tolerated with compound $\mathbf{3 1}$ showing the highest cellular potency in this series.

Table 5. Selected data for Compounds N2 substituted compounds

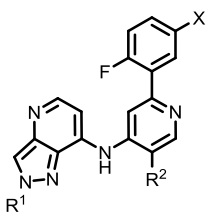

\begin{tabular}{|c|c|c|c|c|c|c|c|}
\hline Cmpd & $\mathbf{x}$ & $\mathbf{R}^{1}$ & $\mathbf{R}^{2}$ & $\mathrm{pIC}_{50}$ & $\begin{array}{c}\text { pEC }_{50} \\
\text { SBE-bla }\end{array}$ & $\begin{array}{c}\text { pEC }_{50} \\
\text { pSMAD } \\
2 / 3 \\
\end{array}$ & $\mathbf{E h}(\mathbf{H} / \mathbf{R})$ \\
\hline 28 & $\mathrm{~F}$ & ó & $\mathrm{H}$ & 7.6 & 6.6 & 5.8 & $.44 / .42$ \\
\hline 29 & $\mathrm{~F}$ & & $\mathrm{CH}_{3}$ & 7.7 & 6.9 & 6.8 & $.79 / .68$ \\
\hline 30 & $\mathrm{Cl}$ & & $\mathrm{H}$ & 7.9 & 7.0 & - & $.52 / .54$ \\
\hline 31 & $\mathrm{Cl}$ & & $\mathrm{CH}_{3}$ & 7.8 & 7.9 & 7.5 & $.46 / .56$ \\
\hline 32 & $\mathrm{Cl}$ & & $\mathrm{H}$ & 7.0 & 6.0 & - & $.36 / .16$ \\
\hline
\end{tabular}

$\mathrm{E}_{\mathrm{h}}=\mathrm{Cl}_{\mathrm{h}} / \mathrm{Q}_{\mathrm{h}}$ where $\mathrm{E}_{\mathrm{h}}=$ Hepatic extraction ratio; $\mathrm{Cl}_{\mathrm{h}}=$ Clearance hepatic $(\mathrm{mL} / \mathrm{min} / \mathrm{kg}) ; \mathrm{Q}_{\mathrm{h}}=$ Hepatic blood flow see ref. $7 \mathrm{~b}-\mathrm{c}$

The piperidine analogs $\mathbf{2 7}$ and $\mathbf{3 2}$ were made to increase solubility and enhance the probability of obtaining a crystal structure of the chemotype bound to ALK5. The basic nitrogen of the piperidine ring could also form a salt bridge with $\mathrm{Asp}_{290}$ and the edge of the piperidine ring could also makes a mainly hydrophobic interaction with the backbone of $\mathrm{Gly}_{322}$ and $\mathrm{Thr}_{323}$ in models. 
The team was pleased that a structure was successfully determined with $2.6 \AA$ resolution with compound 32. Examination of the co-structure in ALK $5^{10}$ confirmed the predicted binding mode of the series (Figure 3 ). The structure shows the N4 of the pyrazolo[4,3-b]pyridine accepting an $\mathrm{H}$-bond from the backbone $\mathrm{NH}$ of $\mathrm{His}_{283}$ at the kinase's hinge region while the $\mathrm{C} 5 \mathrm{C}-\mathrm{H}$ makes a pseudo hydrogen bond ${ }^{10 \mathrm{~g}}$ to the carbonyl oxygen of $\mathrm{Asp}_{281}$. The pyridyl ring of compound $\mathbf{3 2}$ is positioned to hydrogen bond with the conserved water molecule that is coordinated by $\mathrm{Asp}_{351}, \mathrm{Glu}_{245}$ and $\mathrm{Tyr}_{249}$. The phenyl ring, attached at the C2' position of pyridine ring, is oriented towards the back hydrophobic pocket. As compared to our model of compound 2 , Lys $_{232}$ now shifts away from the ligand, no longer H-bonding to the pyridyl $\mathrm{N}$. This is likely due to subtle shift in the H-bonding network induced by an additional H-bond acceptor on the ligand of the parent crystal structure (ref 4) used for modeling compound 2. The parent structure's ligand has a 2-pyridyl ring in the place of compound 32's phenyl ring.

Figure 3. Co crystal structure of compound 32 in ALK5 protein

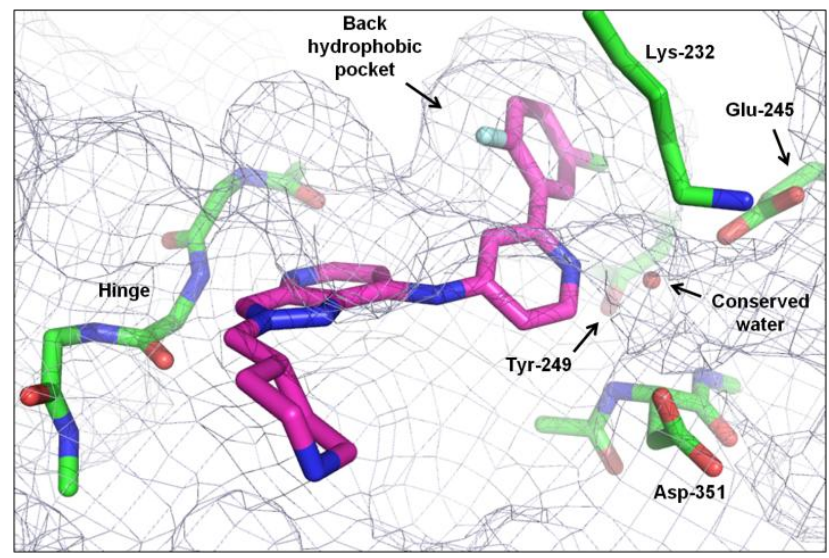

Several representative analogs from the 7-substituted- pyrazolo[4,3b]pyridine series with substituents at the N1 and N2 positions (Tables 6 \& 7) which displayed the highest cellular potency were further profiled to assess their in vitro properties. Analog 22 which initially appeared promising due to cell potency unfortunately had high Cyp 3A4 inhibition $\left(\mathrm{pIC}_{50}=6.1\right)$ and was no longer considered useful.

Compounds 26, 30-31, did not display elevated Cyps (3A4 values of 4.9, 4.9 , and $<4.3$ respectively). Compounds 26 displayed moderate in vivo rat clearance $(42 \mathrm{~mL} / \mathrm{kg} / \mathrm{min})$ with good oral bioavailability $(\mathrm{F} \%=71)$. Unfortunately compounds 26, 30-31 all displayed elevated hERG signal (59\%\&41\%@10uM respectively).

To overcome the hERG inhibition observed in these analogs, a further reduction in lipopholicity was achieved by introducing a 5-fluoro-2methylpyridine group in place of the 2,5-difluorophenyl or 5-chloro-2fluorophenyl group (see analog $\mathbf{1 8}$ in Table 3 and derivatives thereof in Tables 4 \& 5).

Substituent groups R were better tolerated at position N1 (Table 6) than N2 (Table 7) in this series. Simple alkyl groups at position R (33-34 \& 40-41) were similarly potent as the parent 18 with no improvement in in vitro clearance. More polar substitution particularly those in 36-39 and 43-46 appeared to mitigate clearance, and many were advanced to in vivo $\mathrm{PK}$ experiments. The most promising analogs $(36 \mathrm{~F} \%=38 ; 37$ $\mathrm{F} \%=21$ and $43 \mathrm{~F} \%=40$ were tested for hERG inhibition and unfortunately showed elevated hERG signal (42\%, 51\% and 56\%@10uM respectively).

Table 6. Selected data for Compounds N1 substituted compounds<smiles>[R]n1ncc2nccc(Nc3cc(-c4nc(C)ccc4F)ncc3C)c21</smiles>

\begin{tabular}{|c|c|c|c|c|c|}
\hline Cmpd & $\mathbf{R}$ & $\mathrm{pIC}_{50}$ & $\begin{array}{c}\text { pEC }_{50} \\
\text { SBE-bla }\end{array}$ & $\begin{array}{c}\text { pEC }_{50} \\
\text { pSMAD2/3 }\end{array}$ & $\operatorname{Eh}(\mathbf{H} / \mathbf{R})$ \\
\hline 33 & $-\mathrm{CH}_{3}$ & 8.4 & 8.2 & 7.4 & $.56 / .61$ \\
\hline 34 & $-\mathrm{CH}_{2} \mathrm{CH}_{3}$ & 8.7 & 8.1 & 7.3 & $.69 / .69$ \\
\hline 35 & & 7.9 & 7.7 & - & - \\
\hline 36 & & 8.1 & 7.0 & 6.3 & $.3 / .3$ \\
\hline 37 & & 8.1 & 7.2 & 6.4 & $.4 / .3$ \\
\hline 38 & & 8.5 & - & 6.3 & $<.23 / .21$ \\
\hline 39 & & 7.8 & 6.9 & 5.8 & $.28 /<.15$ \\
\hline
\end{tabular}

$\mathrm{E}_{\mathrm{h}}=\mathrm{Cl}_{\mathrm{h}} / \mathrm{Q}_{\mathrm{h}}$ where $\mathrm{E}_{\mathrm{h}}=$ Hepatic extraction ratio; $\mathrm{Cl}_{\mathrm{h}}=$ Clearance hepatic $(\mathrm{mL} / \mathrm{min} / \mathrm{kg}) ; \mathrm{Q}_{\mathrm{h}}=$ Hepatic blood flow see ref. $7 \mathrm{~b}-\mathrm{c}$

Table 7. Selected data for Compounds N2 substituted compounds<smiles>[R]n1cc2nccc(Nc3cc(-c4nc(C)ccc4F)ncc3C)c2n1</smiles>

\begin{tabular}{|c|c|c|c|c|c|}
\hline Cmpd & $\mathbf{R}$ & $\mathrm{pIC}_{50}$ & $\begin{array}{c}\text { pEC }_{50} \\
\text { SBE-bla }\end{array}$ & $\begin{array}{c}\text { pEC }_{50} \\
\text { pSMAD2/3 }\end{array}$ & $\begin{array}{c}\text { Eh } \\
(\mathbf{H} / \mathbf{R})\end{array}$ \\
\hline 40 & $-\mathrm{CH}_{3}$ & 8.4 & 7.1 & 6.5 & $.66 / .46$ \\
\hline 41 & $-\mathrm{CH}_{2} \mathrm{CH}_{3}$ & 8.0 & 7.8 & 6.8 & - \\
\hline 42 & & 8.1 & 6.6 & - & $.38 / .43$ \\
\hline 43 & & 8.1 & 6.8 & 6.3 & $.29 / .3$ \\
\hline 44 & & 8.1 & 7.1 & 6.5 & $.4 / .3$ \\
\hline 45 & & 8.0 & - & 6.6 & $.25 / .16$ \\
\hline 46 & & 7.5 & 6.9 & 6.3 & $.37 / .24$ \\
\hline
\end{tabular}

$\mathrm{E}_{\mathrm{h}}=\mathrm{Cl}_{\mathrm{h}} / \mathrm{Q}_{\mathrm{h}}$ where $\mathrm{E}_{\mathrm{h}}=$ Hepatic extraction ratio; $\mathrm{Cl}_{\mathrm{h}}=$ Clearance hepatic $(\mathrm{mL} / \mathrm{min} / \mathrm{kg}) ; \mathrm{Q}_{\mathrm{h}}=$ Hepatic blood flow see ref. $7 \mathrm{~b}-\mathrm{c}$

At this point in the program we learned of a potential cardiac toxicity associated with modulating ALK5. ${ }^{11}$ The chemistry team was advancing additional ALK5 inhibitors described in a previous article in this journal $^{12 a}$ and had only begun to fully examine compound $\mathbf{3 6}$ (limited selectivity $^{13}$ and in vitro safety data was obtained) when a decision was made to do in vitro safety testing thus necessitating a choice of lead molecule. Although the on target cardiac valvulopathy that was hypothesized from ALK5 inhibition was unrelated to hERG signal ${ }^{14 a}$, the teams nevertheless choose an alternative molecule to compound $\mathbf{3 6}$ for the toxicological studies to remove any potential to confound the results. ${ }^{12 \mathrm{~b}}$ 
In summary, a novel series of ALK5 inhibitors was identified and developed. Starting from screening hit $\mathbf{2}$, by using SBDD and medicinal chemistry knowledge, the team optimized potency, ascertained binding pose (compound 32) and finally improved metabolic stability and bioavailability of this series, culminating in the identification of lead compound 36. However, inhibition of ALK5 was shown to produce significant cardiac toxicity ${ }^{12}$ and lead to the program's termination.

\section{Acknowledgments}

We are grateful to Matthew J. Cukierski, Mary E Carsillo, Ron Eydelloth and Vic Kadambi for the toxicity studies and the staff of the Berkeley Center for Structural Biology for support of beam line 5.0.3 at the Advanced Light Source. The Advanced Light Source is supported by the Director, Office of Science, Office of Basic Energy Sciences, of the U.S. Department of Energy under Contract No. DE-AC02-05CH11231.

\section{References and Notes}

1. a) Yingling, J. M.; Blanchard, K. L.; Sawyer, J. S. Nature Reviews Drug Discovery 2004, 3, 1011. b) Connolly, E. C.; Freimuth, J.; Akhurst, R. J. Int. J. Biol. Sci. 2012, 8, 964. c) Inman, G. J.; Nicolás, F. J.; Callahan, J. F.; Harling, J. D.; Gaster, L. M.; Reith, A.D.; Laping, N. J.; Hill, C. S. Mol. Pharmacol. 2002, 62, 65. d) Jin, C. H.; Krishnaiah, M.; Sreenu, D.; Subrahmanyam, V. B.; Rao, K. S.; Lee, H. J.; Park, S.-J.; Park, H.-J.; Lee, K.; Sheen, Y. Y.; Kim, D.-K. J. Med. Chem. 2014, 57, 4213. e) Fabregat, I.; Fernando, J.; Mainez, J.; Sancho, P. Curr. Pharm. Des. 2014, 20, (17), 2934. f) Fields, S. Z.; Parshad, S.; Anne, M.; Raftopoulos, H.; Alexander, M. J.; Sherman, M. L.; Laadem, A.; Sung, V.; Terpos, E. Expert Opin. Invest. Drugs 2013, 22, (1), 87. g) Ling, L. E.; Lee, W.-C. Curr. Pharm. Biotechnol. 2011, 12, (12), 2190. h) Koh, R. Y.; Lim, C. L.; Uhal, B. D.; Abdullah, M.; Vidyadaran, S.; Ho, C. C.; Seow, H. F. Mol. Med. Rep. 2015, 11, (5), 3808. i) Park, S.-A.; Kim, M.-J.; Park, S.-Y.; Kim, J.S.; Lee, S.-J.; Woo, H. A.; Kim, D.-K.; Nam, J.-S.; Sheen, Y. Y. Cell. Mol. Life Sci. 2015, 72, (10), 2023. j) Bian, F.; Render, J.; Ren, X.-D.; Chio, C.; Chan, K.; Boys, M.; Lala, D. S.; Pocalyko, D. Plast. Reconstr. Surg. 2011, 128, (5), e451. k) Boys, M. L.; Biana, F.; Kramera, J. B.; Chioa, C. L.; Rena, X.-D.; Chena, H.; Barretta, S. D.; Sextona, K. E.; Iulaa, D. M.; Filzena, G. F.; Nguyena, M. N.; Angella, P.; Downsa, V. L.; Wanga, Z. W.; Rahejaa, N.; Ellswortha E. L.; Fakhourya, S.; Brattona, L. D.; Kellera, P. R.; Gowana, R.; Drummonda E. M.; Maitib, S. N.; Henab M. A.; Lub, L.; McConnella, P.; Knafelsa, J. D.; Thanabala, V.; Suna, F.; Alessia, D.; McCarthya, A.; Zhanga, E.; Finzela, B. C.; Patela, S.; Ciottia, S. M.; Eismaa, R.; Paynea, N.A.; Gilbertsena, R. B.; Kostlana, C. R.; Pocalykoa, D. J.; Lalaa D. S. Bioorg. Med. Chem. Lett.2012, 22, (10), 3392.

2. a) Clinical Trials Identifiers: NCT01246986; NCT01582269; NCT01722825; NCT01220271 and NCT01373164 for LY2157299 and NCT 02160106 for EW-7197 b) Herbertz, S.; Sawyer, J. S.; Stauber, A. J.; Gueorguieva, I.; Driscoll, K. E.; Estrem, S. T.; Cleverly, A. L.; Desaiah, D.; Guba, S. C.; Benhadji, K. A.; Slapak, C. A.; Lahn, M. M.; Drug. Des. Devel. Ther. 2015, 9, 4479.

3. Test compounds were screened for TGFBR1 ALK5 (PV5837 Invitrogen) inhibition by use of a LanthaScreen ${ }^{\mathrm{TM}}$ activity assay (Invitrogen Corp. Madison, WI). Solutions of test compounds in DMSO were diluted two-fold serially. Assays were conducted at $15 \mu \mathrm{L}$ volumes consisting of $50 \mathrm{mM}$ HEPES $\mathrm{pH} 7.4,10 \mathrm{mM} \mathrm{NaCl}$, $10 \mathrm{mM} \mathrm{MgCl}_{2}, 0.01 \%$ Brij $^{\circledR} 35,1 \mathrm{mM}$ DTT, $2 \mu \mathrm{M}$ ATP, $1.2 \mu \mathrm{M}$ of Fluorescein-SMAD3 Peptide FAM- $\mathrm{NH}_{2}-$ KVLTQMGSPSIRCSS[PO4]VS (M4337 Invitrogen), $15 \mathrm{nM}$ ALK5 and test compounds at $1 \%$ final DMSO concentration. Reaction was initiated by the addition of ALK5. Assays were incubated for $90 \mathrm{~min}$ at room temperature and then quenched by the addition of $60 \mathrm{mM}$ EDTA and $8 \mathrm{nM}$ Terbium labeled antipSMAD3 Antibody (M4337 from Invitrogen) giving a final concentration of $15 \mathrm{mM}$ EDTA and $2 \mathrm{nM}$ Terbium labeled antipSMAD3 Antibody. Phosphorylated peptide product was quantified by measuring an increase in TR-FRET on a BMG LABTECH PHERAstar plus. For further details see WO/2011/146287

4. PDB ID: 3HMM (Research Collaboration for Structural Bioinformatics) Gellibert, F.; Fouchet, M. H.; Nguyen, V. L.; Wang, R.;
Krysa, G.; de Gouville, A. C.; Huet, S.; Dodic, N. Bioorg. Med. Chem. Lett. 2009, 19, 2277.

5. a) Li, H. Y.; McMillen, W. T.; Heap, C. R.; McCann, D. J.; Yan, L.; Campbell, R. M.; Mundla, S. R.; King, C. H.; Dierks, E. A.; Anderson, B. D.; Britt, K. S.; Huss, K. L.; Voss, M. D.; Wang, Y.; Clawson, D. K.; Yingling, J. M.; Sawyer, J. S. J. Med. Chem. 2008, 51, 2302. b) ref 4 c) Kim, D.; Kim, J.; Park, H. Bioorg \& Med. Chem. 2004, 12, 2013 d) Singh, J.; Chuaqui, C. E.; BoriackSjodin, P. A.; Lee, W.; Pontz, T.; Corbley, M. J.; Cheung, H. K.; Arduini, R. M.; Mead, J. N.; Newman, M. N.; Papadatos, J. L.; Bioorg. Med. Chem. Lett. 2003, 13, 4355.

6. Representative experimental for analogs in Table 1. Compound 3 step a: 2-chloropyridin-4-amine (200mg, $1.56 \mathrm{mmol}), 3-$ chlorophenylboronic acid $(243 \mathrm{mg}, 1.56 \mathrm{mmol})$ and $\mathrm{Pd}\left(\mathrm{PPh}_{3}\right)_{4}(450$ $\mathrm{mg}, 0.39 \mathrm{mmol})$ were mixed in dioxane $(4 \mathrm{~mL}) . \mathrm{K}_{2} \mathrm{CO}_{3}$ saturated solution $(2 \mathrm{~mL})$ was added and the mixture was heated at $120{ }^{\circ} \mathrm{C}$ for 30 minutes in a microwave reactor. The solvent was removed and the crude residue was purified on a silica column eluted with a $0-5 \% \mathrm{MeOH}$ in DCM gradient. Concentration of product containing fractions gave 2-(3-chlorophenyl)pyridin-4-amine (150mg, $47.1 \%$ yield) as a light yellow oil.

Compound 3 step b: 4-bromo-5-methoxyquinoline (174 mg, 0.733 $\mathrm{mmol}$ ), 2-(3-chlorophenyl)pyridin-4-amine ( $150 \mathrm{mg}, 0.733 \mathrm{mmol}$ ), $\mathrm{Pd}_{2}(\mathrm{dba})_{3}$ (168 mg, $\left.0.183 \mathrm{mmol}\right)$, XANTPHOS (106 mg, 0.183 $\mathrm{mmol})$ and sodium 2-methylpropan-2-olate $(211 \mathrm{mg}, 2.199 \mathrm{mmol})$ were mixed in 1,4-Dioxane $(4 \mathrm{~mL})$ and heated at $140{ }^{\circ} \mathrm{C}$ for $1 \mathrm{~h}$ in a microwave reactor. The reaction was concentrated; the crude residue was taken up in $\mathrm{MeOH}$, filtered and subjected to preparative HPLC. N-(2-(3-chlorophenyl)pyridin-4-yl)-5-methoxyquinolin-4amine (compound 3 ) was obtained as a light yellow oil $(55 \mathrm{mg}$, $0.152 \mathrm{mmol}, 20.74 \%$ yield). ${ }^{1} \mathrm{H}$ NMR (400 MHz, METHANOL$\left.\mathrm{d}_{4}\right) \delta \mathrm{ppm} 4.09(\mathrm{~s}, 3 \mathrm{H}) 7.26(\mathrm{~d}, \mathrm{~J}=8.08 \mathrm{~Hz}, 1 \mathrm{H}) 7.42-7.53(\mathrm{~m}, 4$ H) $7.71-7.81(\mathrm{~m}, 2 \mathrm{H}) 7.84-7.93(\mathrm{~m}, 2 \mathrm{H}) 8.08(\mathrm{~d}, \mathrm{~J}=2.27 \mathrm{~Hz}, 1$ H) $8.49(\mathrm{~d}, \mathrm{~J}=6.82 \mathrm{~Hz}, 1 \mathrm{H}) 8.63(\mathrm{~d}, \mathrm{~J}=6.32 \mathrm{~Hz}, 1 \mathrm{H})$

7. a) $\mathrm{LLE}=\mathrm{p}\left(\mathrm{IC}_{50}\right)-\log \mathrm{D}$ see Leeson and Springthorpe Nat. Rev. Drug Discovery 2007, 6(11) $881 ; \mathrm{LE} \approx 1.37 \times \mathrm{p}\left(\mathrm{IC}_{50}\right) / \mathrm{HA}$ where HA = Heavy Atoms see Hopkins et al., Drug Discov. Today 2004, 9, 430. b) Obach Curr. Top. Med Chem 2011, 11, 334. c) Davies and Morris Pharm. Res. 1993, 10, (7), 1093.

8. For a more detailed experimental see WO/2011/146287

9. Test compounds were screened for cellular TGFBR1 ALK5 inhibition by use of a CellSensor ${ }^{\circledR}$ SBE-bla HEK 293T (cat \# K1550, Invitrogen Corp. Madison, WI) cell line. The CellSensor ${ }^{\circledR}$ SBE-bla HEK 293T cell line contains a beta-lactamase reporter gene under control of the SBE response element stably integrated into HEK 293T cells. The SBE response element is a DNA region that binds activated SMADs which results from the binding of TGF $\beta$ to, and subsequent activation of ALK5.

10. a) PDB ID: 5USQ b) The ALK5 catalytic domain (residues 192500) was cloned into the pFastBacHTb vector and recombinant baculovirus was generated and expressed in fusion with an $\mathrm{N}$ terminal 6x poly-histidine tag and TEV cleavage site. Large scale production of recombinant protein was carried out in Spodoptera frugiperda Sf9 cells. The cell pellet was suspended into lysis buffer consisting of $25 \mathrm{mM}$ HEPES ( $\mathrm{pH} 8.0$ ), $1 \mathrm{M} \mathrm{NaCl}, 20 \mathrm{mM}$ imidazole, 3 Roche Complete tablets. The lysate was centrifuged, and clarified supernatant was batch bound with $10 \mathrm{ml}$ of Probond $\mathrm{Ni}$ resin (Invitrogen). The protein was then eluted with buffer containing $25 \mathrm{mM}$ HEPES (pH 7.6), $150 \mathrm{mM} \mathrm{NaCl}$, and $250 \mathrm{mM} \mathrm{im}$ idazole. After tag cleavage, the protein was further purified by size-exclusion chromatography utilizing a Superdex 200 column equilibrated in $25 \mathrm{mM}$ HEPES (pH 7.6), $150 \mathrm{mM} \mathrm{NaCl}, 5 \%$ Glycerol. Fractions containing the protein of interest were pooled, concentrated to $\sim 2 \mathrm{mg} / \mathrm{ml}$ and flash-frozen in liquid nitrogen for storage at $-80^{\circ} \mathrm{C}$. Crystals suitable for data collection were obtained by vapor diffusion in sitting drops at $20^{\circ} \mathrm{C}$. Reservoirs contained $14-18 \%$ PEG $8 \mathrm{~K}$ and $100 \mathrm{mM}$ CHES pH 9.0 -9.4. Crystals that took 7 -10 days to grow were immersed in mother liquor solution containing $22 \%$ ethylene glycol for cryoprotection and flash frozen in liquid nitrogen. Crystals of ALK5 complex grew in the orthorhombic space group P212121 and contain one molecule in the asymmetric unit. Diffraction data to $2.55 \AA$ were collected from single cryogenically protected crystals at beam line 5.0.3 of the Advanced Light Source at Lawrence Berkeley National Laboratory. Data was reduced using the HKL2000 software package.1The structure was determined by molecular replacement with either 
MOLREP2 or PHASER3 of the CCP4 program suite and refined with the program REFMAC.4 several cycles of model building with XtalView5 and refinement were performed for improving the quality of the model. The coordinates and structure factors have been deposited in Protein Data Bank with accession code 5USQ. c) Otwinowski, Z.; Minor, W. 1997, Methods Enzymol. 276, 307. d) Vagin, A.; Teplyakov, A. 1997, MOLREP: an automated program for molecular replacement. J. Appl. Cryst. 30, 1022. e) McCoy, A. J.; Grosse-Kunstleve, R. W.; Adams, P. D.; Winn, M. D.; Storoni, L. C.; Read, R. J.; 2007, Phaser Crystallographic Software. J. Appl. Cryst. 40, 658. f) Murshudov, G. N.; Vagin, A. A.; Dodson, E. J. 1997, Acta Crystallogr. Sect. D 53, 240-255. g) McRee, D. E.; 1999 J. Struct. Biol. 125, 156. h) In accord with Definition of the hydrogen bond (IUPAC Recommendations 2011) Pure Appl. Chem., 83, 8, 1637.

11. Anderton, M. J.; Mellor, H. R.; Bell, A.; Sadler, C.; Pass, M.; Powell, S.; Steele, S. J.; Roberts, R. R. A.; Heier, A. Toxicol. Pathol. 2011 39; 916.

12. a) Wang, H.; Lawson, J. D.; Scorah, N.; Kamran, R.; Hixon, M. S.; Atienza, J.; Dougan, D. R.; Sabat, M. Bioorg. Med. Chem. Lett., 2016, 26, 4334.

13. Compound 36 ALK5 family isozyme profiling selectivity: ALK4 is 39-fold, ALK2 and ALK3 (BMPR1 $\alpha$ ) are each >200-fold, based on 2 pt screening done at $10 \& 1 \mathrm{uM}$, and compared to the in-house determined of ALK5 $\mathrm{IC}_{50}$ value.

14. a) We do not believe hERG activity has any relationship to cardio valvulopathy however we did not want potential $\mathrm{AE}$ to be possibly clouded by or attributed to hERG risk. b) Automated whole cell patch-clamp (Qpatch 16) or conventional whole cell patch-clamp technique was used to record outward potassium currents from a single cell. Conducted at: www.cerep.com

*To whom correspondence should be addressed. Phone (1) 858731 3637. E-mail

mark.sabat@takedasd.com 


$$
\begin{aligned}
& \mathrm{pIC}_{50}=6.2 \\
& \mathrm{E}_{\mathrm{h}}=.9 \\
& \mathrm{LE}=.3 \\
& \mathrm{LLE}=2.5
\end{aligned}
$$

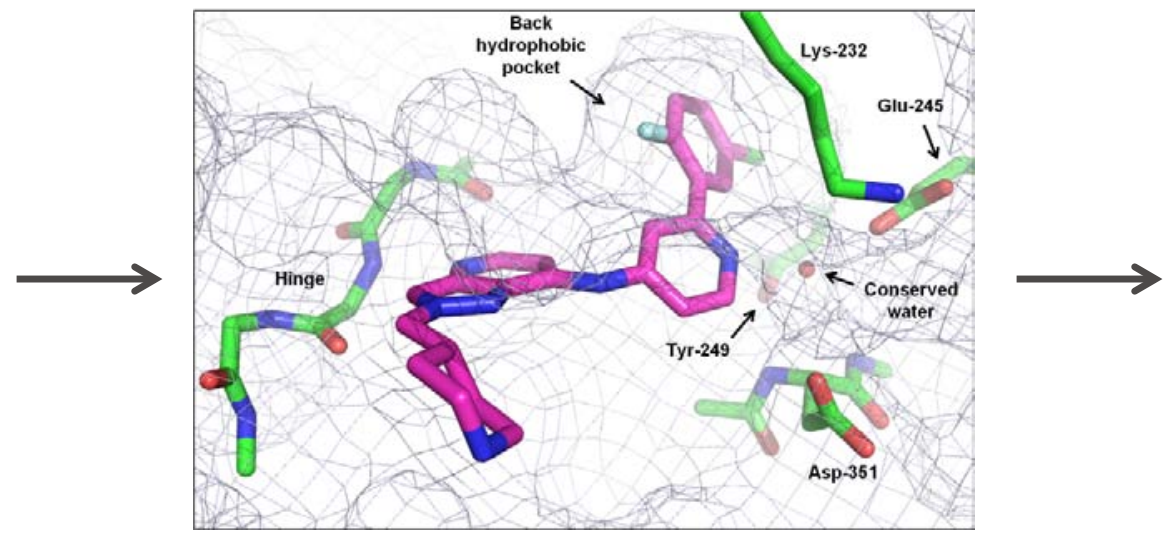

X-ray Co-crystal Structure

\section{in ALK5}

$\mathrm{pIC}_{50}=8.1$

$\mathrm{E}_{\mathrm{h}}=.3 \mathrm{H} / \mathrm{R}$

LLE $=5.6$

$\mathrm{F} \%=38$

LLE= ligand-lipophilicity efficiency $p($ IC50) $-\log D$

$\mathrm{LE}=$ ligand efficiency $\mathrm{LE} \approx 1.37 \times \mathrm{p}(\mathrm{IC} 50) / \mathrm{HA}$ where $\mathrm{HA}=$ heavy atoms

$\mathrm{E}_{\mathrm{h}}=\mathrm{Cl}_{\mathrm{h}} / \mathrm{Q}_{\mathrm{h}}$ where $\mathrm{E}_{\mathrm{h}}=$ Hepatic extraction ratio; $\mathrm{Cl}_{\mathrm{h}}=$ Clearance hepatic $(\mathrm{mL} / \mathrm{min} / \mathrm{kg}) ; \mathrm{Q}_{\mathrm{h}}=$ Hepatic blood flow 